Copyright (C) 2021 by Cherkas Global University

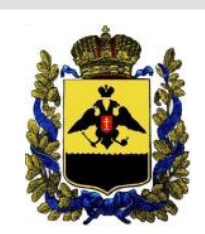

Published in the USA

Bylye Gody

Has been issued since 2006.

E-ISSN: $2310-0028$

2021. 16(4): 1716-1727

DOI: $10.13187 /$ bg.2021.4.1716

Journal homepage:

https://bg.cherkasgu.press

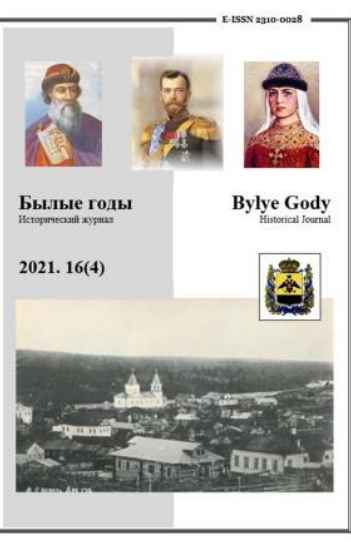

\title{
Ukrainian «Enlightened Bureaucracy» in the System of Higher Education of the Russian Empire in the XIX century
}

\author{
Andrii E. Lebid a b, *, Natal'ya A. Shevchenko b, c \\ a Sumy State University, Sumy, Ukraine \\ b Cherkas Global University, Washington, USA \\ c Volgograd State University, Volgograd, Russian Federation
}

\section{Abstract}

The article reveals the influence of representatives of Ukrainian «enlightened bureaucracy» on the processes of formation and development of higher education system of the Russian Empire in the XIX century, in particular, legal education on the example of the Moscow and St. Petersburg Imperial Universities. To this end, an attempt was made to systematically examine the life and career of P.G. Redkin, a native of Romny (Sumy Region), who was one of the representatives of Ukrainian «enlightened bureaucracy».

Redkin's contribution to the development of higher education system, as well as his influence on the intellectual life of the Russian Empire is considered in this manuscript in several aspects. Firstly, it is educational activity of P.G. Redkin as an Extraordinary and Ordinary Professor, Head of the Chair of Encyclopedia or General Review of Law System of the Moscow Imperial University (1835-1848); Chair of Encyclopedia and History of Law Philosophy of the Saint Petersburg Imperial University (1863-1873), Rector of the Saint Petersburg Imperial University (1873-1876); Honorary Member of this University (1878).

Secondly, it is public and state activity of P.G. Redkin as a founder and publisher of the first law journal in the Russian Empire, founder of educational community, popularizer of universal literacy and professional education of teachers, etc.

Thirdly, it is the scientific activity of P.G. Redkin, the author of fundamental works on the history and philosophy of law, an honorary member of the Imperial Academy of Sciences.

It is shown that scientific, social, state and pedagogical activity of Redkin, Varadinov and other representatives of Ukrainian «enlightened bureaucracy» significantly affected not only the sphere of higher education and science in the Russian Empire, but also the system of state and public relations.

Keywords: enlightened bureaucracy, higher education, pedagogy, history of philosophy of law, legal journalism, educational journalism, Moscow Imperial University, St Petersburg Imperial University, Imperial Academy of Sciences.

\section{1. Введение}

История российской науки периода империи богата выдающимися именами, внесшими свой вклад в развитие не только отечественной, но и мировой науки. Достаточно лишь упомянуть М.В. Ломоносова, Н.И. Лобачевского, Д.И. Менделеева и многих-многих других. Существенный вклад в становление и развитие российской имперской науки внесли уроженцы Украины - родины многих выдающихся ученых и культурных деятелей, чей неоценимый вклад в развитие мировой науки и культуры имеет отклики и сегодня (Bezdrobnyi et al., 2012). Среди них как известные, с мировым именем ученые, имя которых, что говорится «на слуху», так и малоизвестные широкой публике

\footnotetext{
${ }^{*}$ Corresponding author

E-mail addresses: a.lebid@socio.sumdu.edu.ua (A.E. Lebid) 
интеллектуалы, о которых знают разве что специалисты узких научных областей. Много и таких, чьи имена несправедливо забыты.

Данной статьей мы продолжаем серию публикаций о представителях украинской «просвещенной бюрократии», внесших значительный вклад в историю российской имперской науки и образования. Еще одним поводом к подготовке данной работы был тот факт, что лица, о которых идет речь в ней, напрямую связаны с малой родиной одного из авторов - Сумщиной.

В частности, нами и другими исследователями ранее уже были подготовлены и опубликованы материалы об уроженце г. Ромны (Сумская область, Украина), докторе права и философии, меценате и просветителе Н.В. Варадинове (Degtyarev et al., 2018; Degtyarev, 2014a; Degtyarev, 2014b; Lebid et al., 2021a; Lebid et al., 2021b), в которых проанализированы результаты его научной и государственной деятельности.

Еще одним роменчанином, представителем украинской «просвещенной бюрократии», был основатель российской юридической науки, доктор права Петр Григорьевич Редкин - «человек, каких не много», как о нем писал известный историк Т.Н. Грановский. Именно ему и его вкладу в развитие системы высшего образования Российской империи XIX в. посвящена эта статья.

\section{2. Материалы и методы}

В качестве материалов при подготовке рукописи были использованы биобиблиографические материалы, а также документы и материалы из репозитариев Санкт-Петербургского и Московского университетов, раскрывающие особенности развития системы высшего образования Российской империи и связанной с ней научной, педагогической и государственной деятельностью Петра Григорьевича Редкина (Редкин, 1889a-1891b; Редкин, 1841b-1860).

В основу данной работы был положен системный метод научного исследования, использование которого дало возможность комплексного и всестороннего рассмотрения и анализа деятельности П.Г. Редкина как ученого-юриста, педагога, общественного и государственного деятеля.

Кроме того, при подготовке работы нами был использован биографический метод, позволивший упорядочить и увязать факты биографии П.Г. Редкина с конкретными результатами его жизнетворчества. Этот метод также был полезен для понимания основных принципов и подходов при подготовке ученым фундаментального исследования по истории философии права.

Кроме того, данный метод, наряду с использованием исторического метода научного исследования, сделал возможным проследить становление личности П.Г. Редкина по должностной вертикали в сфере образования и науки, высшим проявлением которого стала занимаемая им должность ординарного профессора Московского и Петербургского университетов, а также ректора последнего, почетного члена Императорской Академии наук.

Все это, по нашему мнению, предопределило в некотором роде как проблематику, так и методологию научных исследований Петра Григорьевича Редкина.

\section{3. Обсуждение}

«Просвещенная бюрократия» - понятие, твердо устоявшееся, наравне с понятием «либеральная демократия», в отечественном и зарубежном историческом дискурсе. Среди многочисленных его коннотаций мы придерживаемся той точки зрения, согласно которой к просвещенной бюрократии принадлежали представители прогрессивно мыслящей интеллигенции, для которых общим был взгляд на их миссию и задачи государственного реформирования на принципах гуманизма, прогрессизма и просвещения.

В этом контексте следует отметить ряд научных работ, в которых раскрывается основное содержание понятия «просвещенная бюрократия», в том числе на конкретных примерах ее представителей (Дегтярьов, 2014; Долгих, 2006; Ружицкая, 2008) и др.

Что касается жизни и творчества П.Г. Редкина, как одного из представителей украинской «просвещенной бюрократии», его вклада и влияния на интеллектуальную жизнь российского государства XIX в., в научной литературе существует несколько одностороннее представление о нем, исключительно как о «замечательном, но забытом педагоге» (Помелов, 2018), как «основоположнике русской теоретической педагогики» (Помелов, 2020), «как педагоге-общественнике» (Заварзина, 2013; Супонина, 2010) и др.

По нашему представлению, это несколько ограниченный взгляд на проблему, поэтому необходим комплексный, системный подход, учитывающий не только педагогическую, но и научную, государственную, просветительскую и др. деятельность П.Г. Редкина, поскольку именно в ее разнообразии и разносторонности выражен глубинный смысл прогрессизма и просвещенчества Петра Григорьевича.

Исследований его творческого наследия не так уж и много, в большей степени - жизненного пути, в привязке к творчеству. В основном это материалы энциклопедического характера (Биографический словарь, 1898; Княжнин, 1915; Рябухин, Брянцева, 2005; Ткачук, 2002) и др.

Достаточно велико число научных работ общего характера, в которых жизнь и творчество П.Г. Редкина вскользь упоминается в контексте исторических событий в Российской империи. 
К таковым, к примеру, можно отнести научные работы об академической мобильности студентов российских вузов (Андреев, 2005), функционировании Академии наук (Басаргина, 2008), традициях философского образования в российских университетах (Осипов, 2016; Пустарнаков, 20о3), особенностях развития академической среды в Российской империи (Ростовцев, 2017; Цыганков и др., 2020; Цыганков, 2008), социального и историко-культурного контекста (Омельченко, 20оо; Супронюк, 2009; Курилов, 1898) и др.

Значительный интерес как историографический источник представляют воспоминания о П.Г. Редкине его современников (Модзалевский, 1891; Семенов, 1891; Шимановский, 1891).

Но наибольшую ценность при подготовке данной рукописи представляли работы самого П.Г. Редкина (Редкин, 1889a-1891b; Редкин, 1841a-1860), а также архивные материалы и документы, на основании анализа которых был сформирован комплексный портрет этого представителя украинской «просвещенной бюрократии» (Обозрение, 1873; Обозрение, 1874; Памятная книжка, 1874; Устав, 1836).

\section{4. Результаты}

Личность Петра Григорьевича Редкина (1808-1891 гг.) - уроженца г. Ромны Полтавской губернии (ныне Сумская область, Украина) - интересна с точки зрения того потенциала и свершений на поприще научно-педагогической и государственной деятельности, с какими прошел свой жизненный путь П.Г. Редкин, известный в большей степени как юрист, один из первых профессоров права в Российской империи. Но его деятельность намного разностороннее и исключительно плодотворна во всех сферах ее приложения.

В рамках данной статьи предлагается обобщенный взгляд на наследие Петра Григорьевича как ученого, педагога, государственного и общественного деятеля, представителя «просвещенной бюрократии», почетного мирового судьи, орденоносца (Памятная книжка, 1874). Для начала немного биографической справки, дабы понимать контекст и особенности формирования П.Г. Редкина как выдающегося ученого своего времени. Родился в семье помещика. Выпускник Нежинской гимназии высших наук князя Безбородько, где учился параллельно с Н.В. Гоголем, с которым сохранил теплые дружеские отношения и в дальнейшем (Супронюк, 2009: 153).

Примечателен тот факт, что Петр Григорьевич досрочно окончил данное учебное заведение в 1826 г., пройдя 9-летний курс всего за 6 лет. Успехи его в учебе были настолько выдающимися, что его имя как лучшего учащегося было занесено в специальную книгу лучших учеников - «Liber honoris». Обучение в гимназии заложило фундамент для дальнейшей как научной, так и публицистической деятельности П.Г. Редкина. Он вместе со своими единомышленниками основал интеллектуальный кружок, в котором юные дарования изучали труды Гуго Гроция, И. Канта, И.-Г. Гердера и др., проводя время за дискуссиями и обсуждением прочитанного.

В общем, разносторонность занятий молодого Редкина в стенах Нежинской гимназии благотворно сказалась на развитии его энциклопедического ума и общей начитанности. В частности, в гимназии имелась довольно большая библиотека, в особенности книги по истории на английском и французском языках. Будучи принятым в помощники местного библиотекаря (в том числе благодаря хорошему знанию французского языка), П. Редкин (Рис. 1) имел свободный доступ ко всем фондам и, более того, даже предпринял (вместе с другими участниками кружка) попытку краткого изложения многотомной Всеобщей истории, изданной английским научным сообществом. Все это и многое другое способствовало становлению П.Г. Редкина как ученого-энциклопедиста, педагога, общественного деятеля.

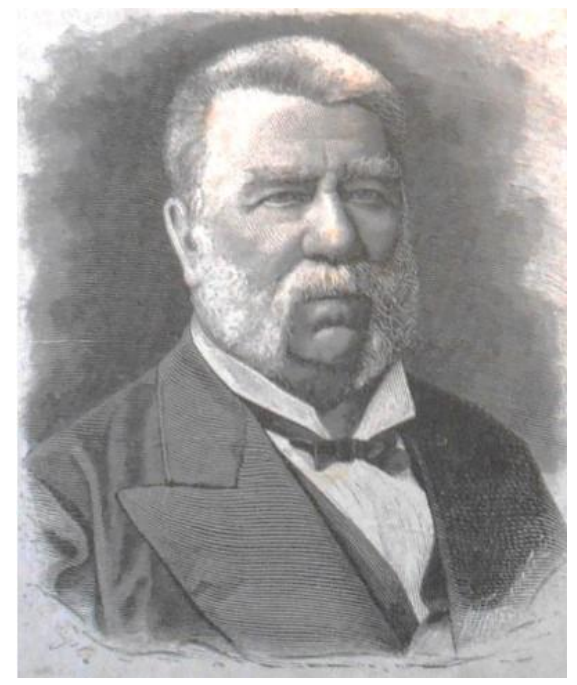

Рис. 1. Петр Григорьевич Редкин (1881 г.) 
После окончания Нежинской гимназии Редкин стал студентом Московского Императорского университета (хотя в мечтах было обучение в Дерптском), поступив на отделение нравственных и политических наук юридического факультета. Учитывая высокие достижения во время учебы в гимназии, его освободили от занятий на подготовительных курсах. Именно обучение в Московском университете сформировало у Петра Григорьевича устойчивое желание построить профессорскую карьеру (Биографический словарь, 1898: 161).

С 1830 г. после отправки из Дерпта и зачисления в середине января 1841 г. в течение 4 лет П.Г. Редкин среди прочих «способных и талантливых молодых людей» (Исаев, 1947: 33) являлся слушателем Берлинского университета (Андреев, 2005: 306).

В Германии он слушает лекции по философии права, философии истории, логике, истории философии, посещает лекции Г.В.Ф. Гегеля, что впоследствии сказалось на его научных предпочтениях. В матрикулах Берлинского университета запись о нем была следующей: «19.01.1831, Петр Григорьевич Редкин, Полтава, Ю., коллежский асессор, Дерпт, 30.04.1834» (Андреев, 2005: 355).

Помимо Берлина, П.Г. Редкин, вероятно, слушал лекции и в Гейдельбергском университете, оставив о нем «сладостнейшие впечатления и воспоминания» (Редкин, 1841b: 277-280; Андреев, 2005: 341).

Бытует мнение, что П.Г. Редкин зарекомендовал себя как «ярый гегельянец», использовавший гегелевскую триадную модель диалектического развития применительно к своим лекциям. Действительно, он был одним из тех, кто популяризировал идеи Гегеля в России, опубликовав, в частности, статью по логике Гегеля (Редкин, 1841a). Тем не менее со временем произошли некоторые как мировоззренческие, так и методологические пертурбации в сторону О. Конта (1865 г.), Э. Гартмана (1872-1873 гг.) и Ч. Дарвина (1874-1875 гг.).

Один из его студентов, уже в Санкт-Петербургском университете, М.В. Шимановский, оставивший воспоминания о своем учителе, упоминает о лекции, на которой Петр Григорьевич «развенчал своего учителя, свой идеал» (Шимановский, 1891). Но тем не менее П.Г. Редкину так и не удалось избавиться от гегельянского «флера» и стать «настоящим» позитивистом. Он никогда «не мог вполне освободиться от усвоенных им в школе Гегеля понятий и приемов» (Биографический словарь, 1898: 166).

В 1835 г., по возращении из Берлина, П.Г. Редкин получает степень доктора права (повторно в 1844 г. - защита проходила согласно учрежденной Высочайшим повелением программе на юридическом факультете Санкт-Петербургского университета, на которой присутствовали члены комиссии - профессора юридического факультета, чиновники II Отделения по особой программе. В качестве материалов для защиты были использованы тезисы по различным разделам юридической науки).

Вместе с тем П.Г. Редкин получил и профессорскую должность в Московском Императорском университете (сначала - экстраординарного профессора, а потом - и ординарного профессора), которую занимал ближайшие несколько лет. Параллельно с профессорской должностью П.Г. Редкин выполнял функции инспектора Александровского сиротского института И Москве, где, помимо прочего, также преподавал юридические дисциплины.

Московский период П.Г. Редкина закончился в 1847 г., когда он вынужден был, как и его соратники по профессорской корпорации - историки Т.Н. Грановский и К.Д. Кавелин, журналист и переводчик Е.Ф. Корш, отказаться преподавать в Московском Императорском университете «вместе с человеком, запятнавшим нравственные ориентиры профессорской корпорации», ...и которому «ставилось на вид негуманное отношение к жене, взяточничество» (Цыганков, 2008: 77). В данном случае речь идет о «грязной истории» с профессором кафедры римской истории и деканом юридического факультета Московского Императорского университета Н.И. Крыловым (Цыганков и др., 2020). Прошения об их увольнении, кроме Т.Н. Грановского, были удовлетворены. Последнему было отказано ввиду того, что он не отслужил положенные 12 лет, согласно обязательствам «за заграничную командировку».

Почти 20 лет (до 1863 г.) П.Г. Редкин не занимался педагогической деятельностью, находясь на чиновничьей службе в Удельном ведомстве, получив там место по рекомендации В.И. Даля. Только в 1863 г. он вернулся к преподаванию, возглавив кафедру энциклопедии и истории философии права в Санкт-Петербургском Императорском университете, где он читал студентам 1 курса юридического факультета энциклопедию юридических и политических наук «по шести лекций в неделю» (Обозрение, 1872: 119).

На существовавших в то время 12 кафедрах факультета работали признанные гении юриспруденции, включая «апологета либерализма» П.Г. Редкина, возглавлявшего сначала кафедру, а позднее, в 1873-1876 гг., ставшего ректором Санкт-Петербургского Императорского университета в чине тайного советника и ординарного профессора, продолжая читать студентам 1 курса лекции по энциклопедии юридических и политических наук «по три лекции в неделю», а студентам 4 курса курс «История философии права» «по две лекции в неделю» (Обозрение, 1873: 116-117). Также он читал курсы «Русские государственные законы», «История философии права и права иностранных государств» и др. 
Работа П.Г. Редкина на юридическом факультете Санкт-Петербургского Императорского университета пришлась на «Золотой век» факультета (1863-1919 гг.), когда Университетский устав 1863 г. расширил полномочия и возможности университетов в части образования и управленческих функций, а на сам факультет вернулись не только научно-педагогические кадры и студенты, но и курсы политэкономии, философии права, статистики и др. В 1878 г. П.Г. Редкин прекратил свою преподавательскую карьеру, поступив на службу председателем Департамента уделов. В 1891 г. его не стало.

Проследив вкратце жизненный и творческий путь П.Г. Редкина, остановимся на его достижениях как педагога, ученого и общественного деятеля. Петр Григорьевич Редкин получил высокое признание своей научной, педагогической, государственной и общественной деятельности: с 1882 г. он - член Государственного Совета, с 1890 г. - почетный член Императорской Академии наук (Басаргина, 2008: 539). Такой почет, согласно §82 Устава Императорской Академии наук 1836 г., могут снискать только знаменитые личности, «известные своими познаниями и любовью к наукам, из русских ученых, приобретших особенную славу сочинениями, относящимися к какой-нибудь из наук, коими Академия занимается» (Устав, 1836). Кроме того, П.Г. Редкин имел чин действительного статского советника (с 1856 г.), тайного советника (с 1864 г.), а с 1880 г. - действительного тайного советника (Волков, 2016). Орденоносец (св. Анны III ст. - 1845 г., св. Анны II ст. - 1852 г.).

Середина XIX ст. в истории Российской империи ознаменовалась растущим влиянием общественности на социальные, культурные, политические и др. процессы внутренней жизни страны, связанные в первую очередь с реформированием государства. Не обошел этот процесс и вопросов педагогики и образования, которые уже не мыслились как исключительно забота государства. Во многом силами общественности вопросы воспитания и образования стали приоритетами ее всесторонней опеки. Активную позицию в этом занимал и П.Г. Редкин.

По его мнению, существовало несколько способов актуализации педагогических проблем и вопросов, среди которых был выпуск педагогических журналов и альманахов, а также создание профессиональных сообществ. Что касается первого, то здесь П.Г. Редкин сыграл значительную роль в развитии педагогической журналистики. В частности, он был соучредителем журнала «Библиотека для воспитания», позднее - «Новая библиотека для воспитания», издававшихся в 40-х гг. XIX. в двух отделениях: для детского чтения и для воспитателей. Именно второе отделение курировал П.Г. Редкин. После переезда в Санкт-Петербург он инициировал издание «Журнала для воспитания», где максимально продуктивно печатался сам. Не менее активное участие П. Редкин принимал и в журнале «Учитель».

Публицистическая деятельность П. Редкина носила прогрессивный характер в том отношении, что он перенимал передовой педагогический опыт европейских стран: летние вакации он, как правило, проводил за границей, изучая особенности организации учебного процесса, читал специальную литературу и проч. Все это нашло свое отражение в тех идеях и мыслях, которые были опубликованы им на страницах педагогических журналов и альманахов (Редкин, 1958).

П.Г. Редкин активно выступал за создание условий и возможностей профессионального развития самих педагогов, имея непосредственный опыт интроспекции проблем учительского сословия во время обучения как в гимназии, так и в университете. С этой целью им предлагалось создание учительских семинарий с целью развития и саморазвития учительских кадров.

Эти идеи выносились Петром Григорьевичем на обсуждение в кругу единомышленников, в частности известного педагога К.Д. Ушинского и других. Практически это реализовалось в создании педагогического сообщества в Санкт-Петербурге, целью которого было объединение педагогов, промоция и внедрение передовых педагогических идей и опыта. Изначально это собрание единомышленников носило частный характер, но позднее, не без протекции попечителя Петербургского учебного округа, Педагогическое общество получило официальный статус, расширяя численность своих членов, в том числе и в провинции. 15 лет кряду П.Г. Редкин избирался председателем данного общества, что было выражением признания его заслуг в деле продвижения педагогических инноваций.

Не менее выдающимся был вклад П.Г. Редкина и в преподавание. Его неизменное «милостивые государи», с чего он начинал всякую свою лекцию, запомнилось студентам, которые очень тепло отзывались о своем учителе как об истинном педагоге, чье призвание - учительство. Петр Григорьевич - «замечательный образец соединения глубоких познаний, трудолюбия, высокой честности и деятельной любви к просвещению»; никто из преподавателей Московского университета не производил на студентов «такого глубокого впечатления, как профессор законоведения и государственного права, в его чтениях было именно то, что могло увлечь молодых людей, - был юношеский жар и глубокое убеждение»; «на лекциях П.Г. Редкина студенты приучались к логической последовательности мысли, к внутренней связи философских понятий»; П.Г. Редкин «любил щегольнуть начитанностью и потому, указывая на источники своей науки, всегда исчислял нам бесконечное количество сочинений на всевозможных языках. Он проповедовал, что так как наука едина, то для того, чтобы знать основательно один предмет, - необходимо изучать и все другие» (Заварзина, 2013). 
Как ученому-юристу П.Г Редкину вменялось чтение на юридическом факультете базовой дисциплины «Энциклопедия законоведения», введенной как обязательная в университеты в период Николая I. Эта нормативная дисциплина заменила собой более общую энциклопедию права. Такая замена произошла в контексте формирования нового свода законов, порученного М.М. Сперанскому и в некотором роде определившего не только структурные, но и содержательные изменения юридических наук и курсов. В новой, несколько упрощенной системе преподавание сводилось к изучению системы законов, «Свода законов Российской империи» (в начале 1833 г. был издан манифест о введении его в действие, начиная с 1835 г.).

Приоритет в обучении отдавался изучению российского законодательства. Это несколько противоречило практике чтения данного курса П.Г. Редкиным, привыкшим к компаративистике отечественного и европейского законодательства и выстраивавшего свои лекции на разборе конкретных кейсов, прецедентов в широком историко-философском и правовом контекстах. Таким образом, фактически им был разработан и внедрен в практику преподавания системный подход к чтению юридических и философских дисциплин.

Успех и харизма П.Г. Редкина как преподавателя несомненны. Об этом свидетельствуют не только отзывы о нем его слушателей, но и тот факт, что посещать его лекции стремились не только студенты-юристы, которым он, собственно, и читал свои курсы, но и студенты других факультетов. Мало того, были случаи, когда студенты специально переводились с других факультетов на юридический, дабы систематически, на постоянной основе посещать занятия, проводимые П.Г. Редкиным.

Отдельно заслуживает внимания вклад П.Г. Редкина в становление и развитие российской юридической науки. В этом контексте рассмотрим его деятельность, связанную с изданием первого научного юридического журнала в Российской империи - «Юридические записки», планировавшегося издаваться «бессрочно» (Редкин, 1841; Редкин, 1842; Редкин, 1859; Редкин, 1860), хотя имеет место мнение, что Записки по большей части являлись научно-юридическим альманахом, нежели научным журналом в классическом его понимании (Омельченко, 200о).

«Юридические записки» - периодическое издание в 5 томах, выпускавшееся доктором права, профессором П.Г. Редкиным в Москве и Санкт-Петербурге: первые два тома были выпущены непосредственно Петром Григорьевичем; тома 3 и 4 - при сотрудничестве с военным юристом, действительным тайным советником К.К. Яневичем-Яневским; 5 том был выпущен последним в 1862 г. без участия П.Г. Редкина.

Миссией журнала, как и в случае с другими проектами П.Г. Редкина, в частности педагогическими, было распространение юридического знания не только среди специалистовюристов, но и ориентация его на непрофессиональные группы с целью популяризации и формирования у обывателей осознанного чувства законности и долга. К примеру, из этой группы в журнале были помещены статьи В. Тарновского «Юридический быт Малороссии» (Редкин, 1841: 30-49), С. Баршева «О влиянии народных предрассудков на определение наказания» (Редкин, 1841: 78-83) и др.; сам П.Г. Редкин написал специальную статью «Об уголовной кодификации» (Редкин, 1841: 409-491). В журнале публиковали свои материалы видные на то время ученые: юрист, криминалист С.В. Баршев; историк, социолог и публицист К.Д. Кавелин; юрист, историк, профессор истории русского права, действительный член Санкт-Петербургской академии наук Н.В Калачов и др.

Следует отметить, что до появления издаваемого П.Г. Редкиным журнала в российской юридической науке отсутствовали фундаментальные периодические издания. Имели место, конечно, единичные издания, но как таковой системной работы в этом направлении не проводилось. Ситуация изменилась с появлением «Журнала правоведения» И. Беллинсгаузена и «Юридических записок» П.Г. Редкина.

Последний заложил в некотором роде стандарты такого типа периодических изданий, после чего уже со второй половины XIX в. количество изданий по юриспруденции существенно увеличивается: «Журнал Министерства юстиции», «Юридический вестник» (Н.В. Калачов), «Юридический журнал» (П.А. Салманов) и др.

Принимая во внимание и научный, и практический опыт П.Г. Редкина, Записки в большой степени содержали материалы историко-правового, философско-правового характера, значительной была практика освещения западноевропейского законодательства (Редкин, 1841: 1-30).

Еще одной сферой непревзойденного гения П.Г. Редкина была его научная деятельность. Его круг научных интересов составляли вопросы истории и философии права, истории философии, истории педагогики, педагогики, правоведения (Ростовцев, 2017: 184).

Как уже было сказано, одно время П.Г. Редкин слыл апологетом гегелевской философии и методологии, триадичной структуры диалектического развития. Именно ему принадлежит одна из первых статей по логике Гегеля. И даже в те периоды, когда он в той или иной степени пересматривал свое научное кредо и принципы, методологическое влияние Гегеля все же заметно прослеживалось как минимум в структуре его курсов: ему принадлежит концепция трех способов преподавания науки права, которые он называл (по степеням важности) генетическим, диалектическим и органическим. 
В его исследованиях по философии права заметны диспозиции российского либерализма конца XIX - начала XX вв. В 1878 г., после выхода в отставку, П.Г. Редкин работает над своим основным сочинением - изданием прочитанных им лекций по истории философии права, результатом чего стало издание в Санкт-Петербургской типографии М.М. Стасюлевича семи томов «Из лекций заслуженного профессора, доктора прав П.Г. Редкина по истории философии права в связи с историей философии вообще» (Редкин, 1889a-1891b).

Смерть П.Г. Редкина в 1891 г. фактически поставила крест на издании последующих его лекций: при жизни ученого были изданы 6 из 7 томов лекций - 7-й том уже вышел после кончины Петра Григорьевича. Таким образом, при его жизни удалось опубликовать лишь первую из четырех частей его лекций -по «истории древней философии права в связи с древней философией вообе».

Что касается участи 2-й, 3-й и 4-й частей лекций (лекции по «средневековой, новой и новейшей истории философии права в связи с философией вообще»), то издатель указывал, что они автором «приведены в такой порядок, что ...для окончательной обработки и выпуска в свет ...не предвидится особенных затруднений и в непродолжительном времени наследники приступят к этому изданию» (Редкин, 1891b: III-IV). Но, как оказалось, случиться этому было не суждено.

Что же касается изданных 7 томов лекций, то они охватывают период от древних теогоний и орфизма до эллинизма. Что примечательно, автор посвящает это издание «бывшим моим слушателям Московскою и Петербургского университетов».

Концептуально П.Г. Редкин предлагает такое рассмотрение древней истории философии права:

а) общество, государство и право неотделимы друг от друга; они по факту соотносятся с человеческим поведением, изучаемым общей для всех них наукой - этикой;

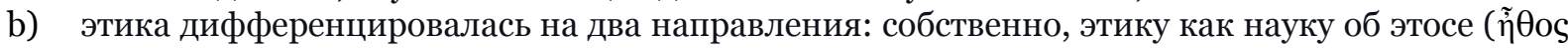
- навык, обычай, душевный склад, нрав, характер) и этос как политическую конструкцию;

c) право не было самостоятельным предметом ни у греков, ни у римлян: оно не имело юридического смысла, а исключительно этический, в широком его значении;

d) общество и государство не мыслятся в категориях бинарных оппозиций; наоборот, первое суть элемент второго.

Заслуга П.Г. Редкина в том, что он одним из первых в Российской империи систематически изложил методологию истории философии права. В этом отношении он был последователем гегелевской триадичной формулы развития, рассматривая эту науку в системе координат общефилософского контекста ее развития, в контексте общественно-государственного обустройства и в контексте общеисторического прогресса. В связи с этим резонной является мысль П.Г. Редкина о том, что правоведение следует рассматривать как триединую науку, фундаментальной для которой выступает юридическая, философская и историческая ее составляющая.

\section{5. Заключение}

В свете сказанного необходимо отметить универсализм, системность и междисциплинарность в работе П.Г. Редкина. По нашему мнению, он не был, как отмечают некоторые исследователи, «прежде всего, педагогом-общественником». Наоборот, его педагогическая деятельность, в которой он, несомненно, преуспел, о чем говорят оставленные о нем воспоминания, органично отражала и дополняла другие аспекты и направления его жизни и творчества: научные, общественные, государственные, просветительские и т.д.

Действительно, П.Г. Редкин - выдающийся педагог, организатор и учредитель педагогических профессиональных сообществ. Своей деятельностью он немало способствовал развитию системы женского образования, неформального образования детей, внедрению системы дошкольных образовательных учреждений и проч. Все это он совмещал с активной публицистической деятельностью по актуальным и злободневным проблемам и вопросам педагогики и права, учитывая опыт европейских стран в системе юридического и общего образования.

Не менее амбициозными были и цели П.Г. Редкина относительно системы высшего образования в Российской империи: подготовка фундаментальных по своему замыслу и охвату читаемых им курсов, работа по изданию научного юридического журнала и др.

Работа Петра Григорьевича на государственной службе также снискала высокую оценку в виде полученных им чинов генеральского ранга, орденов и проч.

Следует также отметить и значительный научный вклад П.Г. Редкина в развитие российской юридической, философской и исторической науки, отразившийся в том числе и в его работе на должности профессора, ректора, почетного члена Императорской Академии наук, доктора права.

\section{Литература}

Андреев, 2005 - Андреев А.Ю. Русские студенты в немецких университетах XVIII - первой половине XIX века. М.: Знак, 2005. 432 с.

Басаргина, 2008 - Басараина Е.Ю. Императорская Академия наук на рубеже XIX-XX веков (Очерки истории). М.: Индрик, 2008. 656 с. 
Бездробний и др. - Бездробний, Ю., Козирсъкий, В., Шендеровсъкий, В. (2012). Видатні українські вчені у світовій науці: Стислий довідник. - Київ: ТОВ «Праймдрук», 2012. 107 с.

Биографический словарь, 1898 - Биографический словарь профессоров и преподавателей Санкт-Петербургского университета за истекшую третью четверть века его существования: 1869-1894. В 2-х т. Т. 2. СПб.: Типография Б.М. Вольфа, 1898. С. 155-168.

Волков, 2016 - Волков С.В. Высшее чиновничество Российской империи. Краткий словарь. М.: Русский фонд содействия образованию и науке, 2016. 800 с.

Дегтярьов, 2014 - Дегтярьов, C.I. (2014). Цивільне чиновництво України у кінці XVIII - першій половині XIX ст. Суми: ТОВ Друкарський дім «Папірус», 2014. 472 с.

Долгих, 2006 - Доләих E.B. К проблеме менталитета российской административной элиты первой половины XIX века: М.А. Корф, Д.Н. Блудов. М.: Индрик, 2006. 344 с.

Заварзина, 2013 - Заварзина Л.Э. Педагог-общественник Петр Григорьевич Редкин // Историко-педагогический журнал. 2013. № 4. С. 30-42.

Исаев, 1947 - Исаев М.M. К вопросу о политической оценке идей классической школы уголовного права в первой половине XIX века. Доклад, сделанный в Военно-юридической академии. М.: Типография В.Ю.А, 1947. 36 с.

Княжнин, 1915 - Княжнин В. Редкин Петр Григорьевич. Русский биографический словарь: в 25 т. Т. 18. СПб.-М., 1915. С. 326-328.

Курилов, 1898 - Курилов И.А. Роменская старина. Исторические, статистические и бытовые записки о городе Ромен и его обывателях. Ромны: Типография Б. Ционсона, 1898. 345 с.

Модзалевский, 1891 - Модзалевский Л.Н. Памяти Петра Григорьевича Редкина // Русская школа. 1891. № 4. С. 50-63.

Обозрение, 1873 - Обозрение преподавания наук в Санкт-Петербургском императорском университете за 1872-1873 академический год. СПб., 1873.

Обозрение, 1874 - Обозрение преподавания наук в Санкт-Петербургском императорском университете за 1873-1874 академический год. СПб., 1874.

Омельченко, 2000 - Омельченко O.A. «Юридические записки» - первый научный юридический журнал России // ФЕМИС. Ежегодник истории права и правоведения. 2000. № 1. С. 211-218.

Осипов, 2016 - Осипов И.Д. Традиции философского образования в Петербургском университете // Вестник СПбГУ. 2016. № 3. С. 54-64.

Памятная книжка, 1874 - Памятная книжка Полтавской губернии за 1874 год. Полтава: Типография Губернского Правления. 1875.

Помелов, 2018 - Помелов В.Б. П.Г. Редкин: замечательный, но забытый педагог (к 210-летию со дня рождения) // Педагогика. Вопросы теории и практики. 2018. № 2 (10). С. 37-41.

Помелов, 2020 - Помелов В.Б. П.Г. Редкин - основоположник русской теоретической педагогики // Вестник Вятского государственного университета. 2020. № 3 (137). С. 170-179.

Пустарнаков, 2003 - Пустарнаков В.Ф. Университетская философия в России. Идеи. Персоналии. Основные центры. СПб.: Изд-во Русского Христианского гуманитарного института, 2003. 919 c.

Редкин, 1958 - Редкин П.Г. Избранные педагогические сочинения. М.: ГУПИ Министерства просвещения РСФСР, 1958. 314 с.

Редкин, 1889a - Редкин П.Г. Из лекций заслуженного профессора, доктора прав П.Г. Редкина по истории философии права в связи с историей философии вообще. Том 1. СПб.: Типография М.М. Стасюлевича, 1889. 442 с.

Редкин, 1889b - Редкин П.Г. Из лекций заслуженного профессора, доктора прав П.Г. Редкина по истории философии права в связи с историей философии вообще. Том 2. СПб.: Типография М.М. Стасюлевича, 1889. 403 с.

Редкин, 1890а - Редкин П.Г. (1890). Из лекций заслуженного профессора, доктора прав П.Г. Редкина по истории философии права в связи с историей философии вообще. Том 3. СПб.: Типография М.М. Стасюлевича, 1890. 475 с.

Редкин, 189ob - Редкин П.Г. (1890). Из лекций заслуженного профессора, доктора прав П.Г. Редкина по истории философии права в связи с историей философии вообще. Том 4. СПб.: Типография М.М. Стасюлевича, 1890. 515 с.

Редкин, $1890 с-$ Редкин П.Г. Из лекций заслуженного профессора, доктора прав П.Г. Редкина по истории философии права в связи с историей философии вообще. Том 5. СПб.: Типография М.М. Стасюлевича, 1890. 492 с.

Редкин, $1891 \mathrm{a}$ - Редкин П.Г. Из лекций заслуженного профессора, доктора прав П.Г. Редкина по истории философии права в связи с историей философии вообще. Том 6. СПб.: Типография М.М. Стасюлевича, 1891. 498 с.

Редкин, $1891 \mathrm{~b}$ - Редкин П.Г. Из лекций заслуженного профессора, доктора прав П.Г. Редкина по истории философии права в связи с историей философии вообще. Том 7. СПб.: Типография М.М. Стасюлевича, 1891. 495 с. 
Редкин, 1841a - Редкин П.Г. Обозрение Гегелевой логики. Москвитянин. 1841. № 4 (8). С. 410. 1841.

Редкин, 1841b - Редкин П.Г. Юридические записки. Том 1. М.: Университетская типография,

Редкин, 1842 - Редкин П.Г. Юридические записки. Том 2. М.: Университетская типография, 1842. $551 \mathrm{c}$.

Редкин, 1859 - Редкин П.Г. Юридические записки Том 3. СПб.: Типография Департамента уделов, 1859. $432 \mathrm{c}$.

Редкин, 1860 - Редкин П.Г. Юридические записки Том 4. СПб.: Типография Департамента уделов, 1860. 665 с.

Ростовцев, 2017 - Ростовцев E.A. Столичный университет Российской империи: ученое сословие, общество и власть (вторая половина XIX - начало XX в.). М.: Политическая энциклопедия, 2017. $903 \mathrm{c}$.

Ружицкая, 2008 - Ружицкая И.В (2008). «Просвещенные бюрократы» - новый тип российских чиновников: опыт характеристики // Вестник РУДН. Серия «История России». 2008. № 1. С. 36-43.

Рябухин, Брянцева, 2005 - Рябухин А.Г., Брянцева Г.В. Профессора Московского университета. 1755-2004 г. Биографический словарь. В 2 т. М.: Изд-во МГУ, 2005.

Семенов, 1891 - Семенов Д.Д. Петр Григорьевич Редкин как педагог // Женское образование. 1891. № 5. C. $481-487$.

Супонина, 2010 - Супонина Е.Г. Общественно-педагогическая деятельность и педагогические взгляды П.Г. Редкина: Дисс. ... канд. пед. наук. Пенза, 2010. 206 с.

Супронюк, 2009 - Супронюк О.К. Н.В. Гоголь и его окружение в Нежинской гимназии. Биобиблиографический словарь. Киев: Академпериодика, 2009. 252 с.

Ткачук, 2002 - Ткачук M. (2002). Рєдкін Петро Григорович. Філософська думка в Україні: Біобібліографічний словник. Київ, 2002. С. 168.

Устав, 1836 - Устав 1836 г. Уставы Академии наук / Ред. Г.К. Скрябин. М., 1975.

Цыганков и др., 2020 - Цыганков Д.А., Андреев А.Ю., Наумов П.Ю. Крыловская история: формирование этики профессорского служения // Вестник Православного Свято-Тихоновского гуманитарного университета. Серия 2 «История. История Русской православной церкви». 2020. № 94. C. 112-130.

Цыганков, 2008 - Цыганков Д.А. Старое и новое в университетских конфликтах 1830-1840-х гг. / ХVIII Ежегодная богословская конференция Православного Свято-Тихоновского гуманитарного университета. 2008. Том 2. С. 74-78.

Шимановский, 1891 - Шимановский М.В. Петр Григорьевич Редкин: (биографический очерк). Одесса, 1891. 33 с.

Degtyarev et al., 2018 - Degtyarev S., Zavhorodnia V., Polyakova L. The Contribution of Nikolai Vasilievich Varadinov to the Development of Russian Civil Law and Historical and Legal Research // Bylye Gody. 2018. 50(4): 1530-1537

Degtyarev, 2014 - Degtyarev S. Varadinov Nikolay Vasilevich - Representative of «Enlightened Bureaucracy»: Bureaucrat's Biography // Russkaya Starina. 2014. 9(1): 4-10.

Lebid et al., 2021a - Lebid A., Kostenko A., Shevchenko N. N.V. Varadinov's research papers and publications as a source on the history of the russian empire of the first half of the 19th century // Bylye Gody. 2021. 16(1): 118-125.

Lebid et al., 2021b - Lebid A., Shevchenko N. Some aspects of the religious life of the Ukrainian provinces of the Russian empire in the first half of the 19th century // Bylye Gody. 2021. 16(2): 629-640.

\section{References}

Andreev, 2005 - Andreev, A.Yu. (2005). Russkie studenty v nemeckih universitetah XVIII - pervoj polovine XIX veka [Russian students at German universities in the 18th and first half of the 19th centuries]. Moskva: Znak, 432 p. [in Russian]

Basargina, 2008 - Basargina, E.Yu. (2008). Imperatorskaya Akademiya nauk na rubezhe XIXXX vekov (Ocherki istorii) [The Imperial Academy of Sciences at the Turn of the Twentieth and Twentieth Centuries (Historical Review)]. Moskva: Indrik, 656 p. [in Russian]

Bezdrobnyi y dr. - Bezdrobnyi, Yu., Kozyrskyi, V., Shenderovskyi, V. (2012). Vydatni ukrainski vcheni $\mathrm{u}$ svitovii nautsi: Styslyi dovidnyk [Prominent Ukrainian scientists in world science]. Kyiv: TOV «Praimdruk», 107 p. [in Ukrainian]

Biograficheskij slovar', 1898 - Biograficheskij slovar' professorov i prepodavatelej Sankt-Peterburgskogo universiteta za istekshuyu tret'yu chetvert' veka ego sushchestvovaniya: 1869-1894 [Biographical Dictionary of Professors and Lecturers of St. Petersburg University in the Third Quarter of a Century of its Existence: 18691894]. V 2-h t. T.2. SPb.: Tipografiya B.M. Vol'fa, 1898. Pp. 155-168. [in Russian]

Volkov, 2016 - Volkov, S.V. (2016). Vysshee chinovnichestvo Rossijskoj imperii. Kratkij slovar' [The higher officials of the Russian Empire. A Concise Dictionary]. Moskva: Russkij fond sodejstviya obrazovaniyu i nauke, 800 p. [in Russian] 
Dehtiarov, 2014 - Dehtiarov, S.I. (2014). Tsyvilne chynovnytstvo Ukrainy u kintsi XVIII - pershii polovyni XIX st. [The Ukrainian civil service in the late 18th century and the first half of the 19th century]. Sumy: TOV Drukarskyi dim «Papirus», 472 p. [in Ukrainian]

Dolgih, 2006 - Dolgih, E.V. (2006). K probleme mentaliteta rossijskoj administrativnoj elity pervoj poloviny XIX veka: M.A. Korf, D.N. Bludov [To the Mentality Problem of the Russian Administrative Elite of the First Half of the 19th Century: M.A. Korff, D.N. Bludov]. Moskva: Indrik, 344 p. [in Russian]

Zavarzina, 2013 - Zavarzina, L.E. (2013). Pedagog-obshchestvennik Pyotr Grigor'evich Redkin [Community educator Pyotr Grigorievich Redkin]. Istoriko-pedagogicheskij zhurnal. 4: 30-42. [in Russian]

Isaev, 1947 - Isaev, M.M. (1947). K voprosu o politicheskoj ocenke idej klassicheskoj shkoly ugolovnogo prava v pervoj polovine XIX veka. Doklad, sdelannyj v Voenno-YUridicheskoj Akademii [On the Political Assessment of the Ideas of the Classical School of Criminal Law in the First Half of the Nineteenth Century. Report delivered at the Military Legal Academy]. Moskva: Tipografiya V.Yu.A,. 36 p. [in Russian]

Knyazhnin, 1915 - Knyazhnin, V. (1915). Redkin Petr Grigor'evich [Redkin Pyotr Grigorievich]. Russkij biograficheskij slovar': v 25 t. T. 18. SPb., Moskva. Pp. 326-328. [in Russian]

Kurilov, 1898 - Kurilov, I.A. (1898). Romenskaya starina. Istoricheskie, statisticheskie i bytovye zapiski o gorode Romen i ego obyvatelyah [Romain antiquity. Historical, statistical and household notes on the town of Romain and its inhabitants]. Romny: Tipografiya B. Cionsona, 345 p. [in Russian]

Modzalevskij, 1891 - Modzalevskij, L.N. (1891). Pamyati Petra Grigor'evicha Redkina [In memory of Pyotr Grigorievich Redkin]. Russkaya shkola. 4: 50-63. [in Russian]

Obozrenie, 1873 - Obozrenie prepodavaniya nauk v Sankt-Peterburgskom imperatorskom universitete za 1872-1873 akademicheskij god [Review of the teaching of science at the Imperial University of St Petersburg for the academic year 1872-1873]. Sankt-Peterburg, 1873. [in Russian]

Obozrenie, 1874 - Obozrenie prepodavaniya nauk v Sankt-Peterburgskom imperatorskom universitete za 1873-1874 akademicheskij god [Review of the teaching of science at the Imperial University of St Petersburg for the academic year 1873-1874]. Sankt-Peterburg, 1874. [in Russian]

Omel'chenko, 2000 - Omel'chenko, O.A. (2000). «Yuridicheskie zapiski» - pervyj nauchnyj yuridicheskij zhurnal Rossii ["Yuridicheskie Zapiski - Russia's first academic law journal]. FEMIS. Ezhegodnik istorii prava i pravovedeniya. 1: 211-218. [in Russian]

Osipov, 2016 - Osipov, I.D. (2016). Tradicii filosofskogo obrazovaniya v Peterburgskom universitete [The tradition of philosophy education at the University of St Petersburg]. Vestnik SPbGU. 3: 54-64. [in Russian]

Pamyatnaya knizhka, 1874 - Pamyatnaya knizhka Poltavskoj gubernii za 1874 god [Commemorative book of Poltava province for 1874]. Poltava: Tipografiya Gubernskogo Pravleniya. 1875. [in Russian]

Pomelov, 2018 - Pomelov, V.B. (2018). P.G. Redkin: zamechatel'nyj, no zabytyj pedagog (k 210-letiyu so dnya rozhdeniya) [P.G. Redkin: a remarkable but forgotten educator (on the 210th anniversary of his birth)]. Pedagogika. Voprosy teorii i praktiki. 2(10): 37-41. [in Russian]

Pomelov, 2020 - Pomelov, V.B. (2020). P.G. Redkin - osnovopolozhnik russkoj teoreticheskoj pedagogiki [P.G. Redkin - founder of Russian theoretical pedagogy]. Vestnik Vyatskogo gosudarstvennogo universiteta. 3(137): 170-179. [in Russian]

Pustarnakov, 2003 - Pustarnakov, V.F. (2003). Universitetskaya filosofiya v Rossii. Idei. Personalii. Osnovnye centry [University philosophy in Russia. Ideas. Personalities. Main centres]. SPb.: Izd-vo Russkogo Hristianskogo gumanitarnogo instituta, 919 p. [in Russian]

Redkin, 1958 - Redkin, P.G. (1958). Izbrannye pedagogicheskie sochineniya [Selected pedagogical works]. Moskva: GUPI Ministerstva prosveshcheniya RSFSR, 1958. 314 s. [in Russian]

Redkin, 1889a - Redkin, P.G. (1889). Iz lekcij zasluzhennogo professora, doktora prav P.G. Redkina po istorii filosofii prava v svyazi s istoriej filosofii voobshche. Tom 1 [From lectures by Emeritus Professor, Doctor of Law P.G. Redkin on the history of the philosophy of law in connection with the history of philosophy in general]. Sankt-Peterburg: Tipografiya M.M. Stasyulevicha, 442 p. [in Russian]

Redkin, 1889b - Redkin, P.G. (1889). Iz lekcij zasluzhennogo professora, doktora prav P.G. Redkina po istorii filosofii prava v svyazi s istoriej filosofii voobshche. Tom 2 [From lectures by Emeritus Professor, Doctor of Law P.G. Redkin on the history of the philosophy of law in connection with the history of philosophy in general]. Sankt-Peterburg: Tipografiya M.M. Stasyulevicha, 403 p. [in Russian]

Redkin, 1890a - Redkin, P.G. (1890). Iz lekcij zasluzhennogo professora, doktora prav P.G. Redkina po istorii filosofii prava v svyazi s istoriej filosofii voobshche. Tom 3 [From lectures by Emeritus Professor, Doctor of Law P.G. Redkin on the history of the philosophy of law in connection with the history of philosophy in general]. Sankt-Peterburg: Tipografiya M.M. Stasyulevicha, 475 p. [in Russian]

Redkin, 189ob - Redkin, P.G. (1890). Iz lekcij zasluzhennogo professora, doktora prav P.G. Redkina po istorii filosofii prava v svyazi s istoriej filosofii voobshche. Tom 4 [From lectures by Emeritus Professor, Doctor of Law P.G. Redkin on the history of the philosophy of law in connection with the history of philosophy in general]. Sankt-Peterburg: Tipografiya M.M. Stasyulevicha, 515 p. [in Russian]

Redkin, 189oc - Redkin, P.G. (1890). Iz lekcij zasluzhennogo professora, doktora prav P.G. Redkina po istorii filosofii prava v svyazi s istoriej filosofii voobshche. Tom 5 [From lectures by Emeritus Professor, 
Doctor of Law P.G. Redkin on the history of the philosophy of law in connection with the history of philosophy in general]. Sankt-Peterburg: Tipografiya M.M. Stasyulevicha, 492 p. [in Russian]

Redkin, 1891a - Redkin, P.G. (1891). Iz lekcij zasluzhennogo professora, doktora prav P.G. Redkina po istorii filosofii prava $\mathrm{v}$ svyazi $\mathrm{s}$ istoriej filosofii voobshche. Tom 6 [From lectures by Emeritus Professor, Doctor of Law P.G. Redkin on the history of the philosophy of law in connection with the history of philosophy in general]. Sankt-Peterburg: Tipografiya M.M. Stasyulevicha, 498 p. [in Russian]

Redkin, 1891b - Redkin, P.G. (1891). Iz lekcij zasluzhennogo professora, doktora prav P.G. Redkina po istorii filosofii prava $\mathrm{v}$ svyazi $\mathrm{s}$ istoriej filosofii voobshche. Tom 7 [From lectures by Emeritus Professor, Doctor of Law P.G. Redkin on the history of the philosophy of law in connection with the history of philosophy in general]. Sankt-Peterburg: Tipografiya M.M. Stasyulevicha, 495 p. [in Russian]

Redkin, 1841a - Redkin, P.G. (1841). Obozrenie Gegelevoj logiki [A review of Hegelian logic]. Moskvityanin. 4(8): 410. [in Russian]

Redkin, 1841b - Redkin, P.G. (1841). Yuridicheskie zapiski. Tom 1 [Legal Notes]. Moskva: Universitetskaya tipografiya. [in Russian]

Redkin, 1842 - Redkin, P.G. (1842). Yuridicheskie zapiski. Tom 2 [Legal Notes]. Moskva: Universitetskaya tipografiya,. 551 p. [in Russian]

Redkin, 1859 - Redkin, P.G. (1859). Yuridicheskie zapiski Tom 3 [Legal Notes]. Sankt-Peterburg: Tipografiya Departamenta udelov, 432 p. [in Russian]

Redkin, 1860 - Redkin, P.G. (1860). Yuridicheskie zapiski Tom 4 [Legal Notes]. Sankt-Peterburg: Tipografiya Departamenta udelov, 665 p. [in Russian]

Rostovcev, 2017 - Rostovcev, E.A. (2017). Stolichnyj universitet Rossijskoj imperii: uchyonoe soslovie, obshchestvo i vlast' (vtoraya polovina XIX -nachalo XX v.) [The Metropolitan University of the Russian Empire: academia, society and power (second half of the nineteenth and early twentieth centuries)]. Moskva: Politicheskaya enciklopediya, 903 p. [in Russian]

Ruzhickaya, 2008 - Ruzhickaya, I.V (2008). «Prosveshchennye byurokraty» - novyj tip rossijskikh chinovnikov: opyt kharakteristiki ["Enlightened bureaucrats" - a new type of Russian officials: experience of characterisation]. Vestnik RUDN. Seriya Istoriya Rossii. 1: 36-43 [in Russian]

Ryabuhin, Bryanceva, 2005 - Ryabuhin, A.G., Bryanceva, G.V. (2005). Professora Moskovskogo universiteta. 1755-2004 g. Biograficheskij slovar'. V 2 t. [Professors of Moscow University. 1755-2004 Biographical dictionary]. Moskva: Izd-vo MGU. [in Russian]

Semyonov, 1891 - Semyonov, D.D. (1891). Petr Grigor'evich Redkin kak pedagog [Pyotr Grigorievich Redkin as a teacher]. Zhenskoe obrazovanie. 5: 481-487. [in Russian]

Suponina, 2010 - Suponina, E.G. (2010). Obshchestvenno-pedagogicheskaya deyatel'nost' i pedagogicheskie vzglyady P. G. Redkina [P.G. Redkin's social and pedagogical activities and pedagogical views]: dis. ... kand. ped. nauk. Penza, 2010. 206 s. [in Russian]

Supronyuk, 2009 - Supronyuk, O.K. (2009). N.V. Gogol' i ego okruzhenie v Nezhinskoj gimnazii. Biobibliograficheskij slovar' [N.V. Gogol and his entourage at Nizhyn Gymnasium. Biobibliographical dictionary]. Kiev: Akademperiodika, 252 p. [in Russian]

Tkachuk, 2002 - Tkachuk, M. (2002). Redkin Petro Hryhorovych [Redkin Petro Grygorovych]. Filosofska dumka v Ukraini: Biobibliohrafichnyi slovnyk. Kyiv. P. 168 [in Ukrainian]

Ustav, 1836 - Ustav 1836 g. [Statute of 1836.]. Ustavy Akademii nauk. Red. G.K. Skryabin. Moskva, 1975. [in Russian]

Cygankov i dr., 2020 - Cygankov, D.A., Andreev, A.Yu., Naumov, P.Yu. (2020). Krylovskaya istoriya: formirovanie etiki professorskogo sluzheniya [Krylovian history: shaping an ethos of professorial service]. Vestnik Pravoslavnogo Svyato-Tihonovskogo gumanitarnogo universiteta. Seriya 2: Istoriya. Istoriya Russkoj pravoslavnoj cerkvi. 94: 112-130. [in Russian]

Cygankov, 2008 - Cygankov, D.A. (2008). Staroe i novoe v universitetskih konfliktah 1830-1840-h gg. [Old and new in the university conflicts of the 1830s and 1840s]. XVIII Ezhegodnaya bogoslovskaya konferenciya Pravoslavnogo Svyato-Tihonovskogo gumanitarnogo universiteta. 2: 74-78. [in Russian]

Shimanovskij, 1891 - Shimanovskij, M.V. (1891). Pyotr Grigor'evich Redkin: (biograficheskij ocherk)

[Peter Grigorievich Redkin: (Biographical sketch)]. Odessa, 33 p. [in Russian]

Degtyarev, 2014a - Degtyarev, $S$. (2014). The History of Bureaucracy of the Russian Empire in the Russian historiography of XIX - early XX century. Bylye Gody. 34(4): 554-558.

Degtyarev et al., 2018 - Degtyarev, S., Zavhorodnia, V., Polyakova, L. (2018). The Contribution of Nikolai Vasilievich Varadinov to the Development of Russian Civil Law and Historical and Legal Research. Bylye Gody. 50(4): 1530-1537

Degtyarev, 2014b - Degtyarev, S. (2014). Varadinov Nikolay Vasilevich - Representative of «Enlightened Bureaucracy»: Bureaucrat's Biography. Russkaya Starina. 9(1): 4-10.

Lebid et al., 2021a - Lebid, A., Kostenko, A., Shevchenko, N. (2021). N.V. Varadinov's research papers and publications as a source on the history of the russian empire of the first half of the 19th century. Bylye Gody. 16(1): 118-125.

Lebid et al., 2021b - Lebid, A., Shevchenko, N. (2021). Some aspects of the religious life of the Ukrainian provinces of the Russian empire in the first half of the 19th century. Bylye Gody. 16(2): 629-640. 


\section{Украинская «просвещенная бюрократия» в системе высшего образования Российской империи XIX в.}

Андрей Евгеньевич Лебедь a , b * , Наталья Александровна Шевченко b c

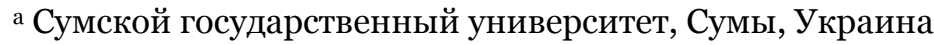

b Черкас глобальный университет, Вашингтон, США

с Волгоградский государственный университет, Волгоград, Российская Федерация

Аннотация. В статье раскрывается влияние представителей украинской «просвещенной бюрократии» на процессы становления и развития системы высшего образования Российской империи XIX в., в частности юридического образования на примере Московского и СанктПетербургского Императорских университетов. С этой целью предпринята попытка систематического рассмотрения жизненного и творческого пути одного из представителей украинской «просвещенной бюрократии», уроженца г. Ромны Сумской области П.Г. Редкина.

Вклад П.Г. Редкина в развитие системы высшего образования, а также его влияние на интеллектуальную жизнь Российской империи рассматривается в представленной статье в нескольких аспектах. Во-первых, это педагогическая деятельность П.Г. Редкина на должности экстраординарного и ординарного профессора, заведующего кафедрой энциклопедии или общего обозрения системы законоведения Московского Императорского университета (1835-1848 гг.); кафедры энциклопедии и истории философии права Санкт-Петербургского Императорского университета (1863-1873 гг.), ректора Санкт-Петербургского Императорского университета (18731876 гг.); почетного члена этого университета (1878 г.).

Во-вторых, это общественная и государственная деятельность П.Г. Редкина как учредителя и издателя первого юридического научного журнала в Российской империи, основателя педагогического сообщества, популяризатора всеобщей грамотности и профессионального образования педагогов и т.д.

B-третьих, это научная деятельность П.Г. Редкина - автора фундаментальных работ по истории и философии права, почетного члена Императорской Академии наук.

Показано, что научная, общественная, государственная и педагогическая деятельность представителей украинской «просвещенной бюрократии», таких как П.Г. Редкин, Н.В. Варадинов и других существенно повлияла не только на сферу высшего образования и науку в Российской империи, но и систему государственных и общественных отношений.

Ключевые слова: просвещенная бюрократия, высшее образование, педагогика, история философии права, юридическая журналистика, педагогическая журналистика, Московский Императорский университет, Санкт-Петербургский Императорский университет, Императорская Академия наук.

\footnotetext{
* Корреспондирующий автор

Адреса электронной почты: a.lebid@socio.sumdu.edu.ua (А. Лебедь) 